1994

\title{
Private Acts in Public Places: A Social History of Divorce in the Formative Era of American Family Law
}

Richard H. Chused

New York Law School, richard.chused@nyls.edu

Follow this and additional works at: https://digitalcommons.nyls.edu/fac_books

\section{Recommended Citation}

Chused, Richard H., "Private Acts in Public Places: A Social History of Divorce in the Formative Era of American Family Law" (1994). Books. 58.

https://digitalcommons.nyls.edu/fac_books/58 


\section{Private Acts in Public Places}

A Social History of Divorce in the Formative Era of American Family Law

Richard H. Chused

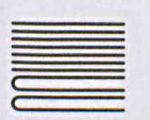

University of Pennsylvania Press

Philadelphia 
Copyright (C) 1994 by Richard H. Chused

All rights reserved

Printed in the United States of America

Library of Congress Cataloging-in-Publication Data

Chused, Richard H., 1943-

Private acts in public places: a social history of divorce in the formative era of American family law / Richard H. Chused.

$$
\text { P. } \mathrm{cm} \text {. }
$$

Includes bibliographical references and index.

ISBN 0-8122-3202-X (alk. paper)

I. Divorce-Law and legislation-United States-History-19th century. 2. Divorce-

Law and legislation-Maryland-History-Igth century. 3. Divorce-United States-

History - 19th century. 4. Divorce-Maryland-History-19th century. 5. United

States-Social conditions-To 1865. I. Title.

KF535.C48 1994

$346.730 \mathrm{I}^{\prime} 66-\mathrm{dc20}$

$[347.306166$

Dedicated with love to my wife, Elizabeth Langer, and our sons, Ben Chused and Sam Langer. 


\section{Contents}

I. Introduction

2. Miscreant Women and Male Divorce:

Family Discord Before I805

Introduction

Regional Differences and the Impact of Chancery

$$
\text { Courts }
$$

The Impact of Race on Early Legislative Divorce

The "Marriage" of Electoral and Divorce Reform

Pre-I805 Legislative Divorces

3. Political Reform and Family Law at the Turn of the Nineteenth Century

Introduction

Legislative Divorce Reform: Cruelty and

Male Adultery Grounds for Private Acts

Rumbles of Discontent: Legislative Controversy and Social Discord

Emergence of Children as a Family Law Consideration

4. Religious and Political Maneuvering:

The Disappearance of $A$ Vinculo Divorce, I8I6-I825

The Rise of Partial Divorce

Partial Divorce and the Economic Interests of Marriage

Child Custody

5. The State of Divorce Law in I825:

The Import of Sarah and Charles Warfield's Saga 
6. The Revival of $A$ Vinculo Divorce and a Child Custody Twist, I826-I836

Introduction

The Politics of Divorce

The Contours of Divorce

The Contours of Marital Property Rules

Children and Divorce

7. The Arrival of Judicial Divorce, $1837-184 \mathrm{I}$

The Politics of General Divorce Legislation

History of Early General Divorce Bills

Links Between Divorce Reform and Married Women's Property Acts

Conclusion: "Liberalism" and Legislative Reform

8. The Demise of Legislative Divorce

Introduction

The Hiatus in Adoption of Private Bills

Concurrent Jurisdiction: Family Law Complexities After Renewal of the Private Bill Process

Alimony After Married Women's Property Reforms

9. Epilogue: The Long-Term Impact of the Legislative Divorce Process

Appendices

I. Tables

2. Process Proposals, General Bill Proposals, and Statutes

3. The Warfield v. Warfield and

Thomas $\mathcal{v}$. Thomas Pamphlets

Index

\section{Introduction}

Before I84I, divorce was a legislative affair in Maryland. Those wishing to divorce sought the aid of representatives in the House of Delegates of the General Assembly, who filed petitions in the lower house seeking passage of private acts ending the marriages of their constituents. Between 1790 and 1850 , the state legislature passed 549 divorce acts and three acts of annulment. ${ }^{1}$ During the $184 \mathrm{I}$ legislative session, Maryland's courts gained authority, concurrent with the legislature, to sever marital bonds. ${ }^{2}$ Only in $185 \mathrm{I}$, after the new state constitution's provision barring legislative divorce took effect, was the General Assembly ousted from day-to-day oversight of family life. ${ }^{3}$

The first private divorce bill passed after the Revolutionary War was obtained in 1790 by John Sewell, of Talbot County, Maryland. ${ }^{4}$ The act's preamble instructs us that his wife, Eve Sewell, was convicted in county court of adultery for bearing a mulatto child. Mother and child were condemned to servitude. The General Assembly granted John a divorce, taking care in the legislation to protect the legitimacy of the white children of John Sewell born before Eve's conviction. ${ }^{5}$ Statements confirming the legitimacy of children were common in the early private divorce acts, most of which were adopted on adultery grounds. Of the fifty legislative divorces or annulments passed between 1790 and I8Is, thirty-nine, or 78 percent, had clauses protecting the legitimacy of children of the severed marriages. ${ }^{6}$

Though Eve's behavior must have been widely condemned, John struggled for more than two years to obtain his divorce. He first petitioned for a private bill at the 1788 session. The effort failed in the House of Delegates by a 34 to 22 vote despite a statement from the committee considering Sewell's petition that "sufficient evidence has been adduced to establish ... [ [the facts] as represented" and a recommendation that "an act ought immediately to pass annulling the said marriage agreeably to the prayer of the said petition." 7 As John Sewell discovered, the General Assembly was reluctant to grant divorces to anyone during the last decade of the eighteenth-century. 
More than five decades after the Sewell divorce, by a simple, unedifying one-line statute, "Eliza Gibson, of the city of Baltimore" was "divorced from her husband, Edmund D. Gibson, a vinculo matrimonii." 8 Obviously, significant changes had occurred between the Sewell and Gibson divorces. Petitioners were generally rural and male before 1800. By mid-century significant numbers of urban women were seeking legislative assistance. ${ }^{9}$ In 1850, the presence of an "immoral" wife was not the obvious or only factor sparking the passage of private divorce bills. Middle-class and urban pressures worked to expand the scope of divorce. ${ }^{10} \mathrm{By} 184 \mathrm{O}$, the acts often were ludicrously simple, and consideration on the floor of the legislature was frequently fast and uneventful.

The simple, often opaque, quality of many of the mid-nineteenthcentury private divorce acts, ${ }^{11}$ however, hides some major conflicts. Though the extant legislative records usually reveal little controversy, severance of nineteenth-century marital ties was sometimes as fiery and unpleasant as our own contemporary experience. During the first half of the nineteenth century, romantic expectations for marriage increased, domestic obligations of wives expanded, and the number of husbands working outside the home to provide their families with economic support rose. Each of these developments created the potential for new forms of bitterness when marriages dissolved. Heavenly romance could convert to hatred; women's changing roles upset traditional men; and failure of husbands to support their families left freshly domesticated wives with few options for survival. Acrimony about children also heightened the unpleasantness of some legislative divorce disputes. By the 1820 soungsters, often viewed in colonial times as economic assets of fathers, were thought by many to be malleable creatures needing intellectual, moral, and emotional guidance to become productive adults. Nineteenth-century disputes about their supervision, therefore, might slip into arguments about the respective worth of mother and father.

Disappointed expectations, economic difficulties, personal anger, and the status of children were not the only causes of legislative controversy. Though the private bill debates, taken one at a time, usually reveal little of note, the totality of legislative trends, such as rates of bill failure or the frequency of amendment proposals, provides clues to the cultural, politi$\mathrm{cal}$, and religious debates in society at large. Legislative conflicts rooted in strands of political, economic, religious, and cultural thought were often more important than the facts of any particular case, even in the midst of open and tumultuous family discord. In addition, many spouses petitioned the legislature for a divorce not to escape the depredations or offenses of a mate still living in the household, but to gain their economic and social freedom from a relationship which had de facto ended at an earlier time. Whether these petitions were filed by an abandoned woman, a deserted man, or separated spouses cooperating in efforts to end their relationship, opposition to the divorce had to be manufactured by the General Assembly. Such parties were unlikely to create discord on their own. The significant increase between $\mathrm{I} 800$ and $\mathrm{I} 840$ in both the divorce rate and the proportion of legislative petitions granted by the General Assembly ${ }^{12}$ confirms that mobility, consensual divorce, ${ }^{13}$ desertion, ${ }^{14}$ and urban disarray were increasing in Maryland, as in the Northeast and West. ${ }^{15}$ The legislative divorce process, therefore, could not be conflict-free. The wish to help those in desperate straits conflicted with traditional attitudes opposing divorce. Though careful factual scrutiny of divorce bills was sometimes frustrated by the clever preparation of individuals or couples cooperating in the presentation of their case to the General Assembly, the domain available for conflict was spacious - roomy enough to allow political, economic, religious, and cultural disputes to influence many family law debates.

Maryland presents an especially important laboratory for exploration of divorce in the formative decades of the republic. We can watch the vagaries of the legislative process unfold in a place that was enormously diverse in its religious, cultural, commercial, and political leanings. The history of Maryland's legislative divorce process brings to light new data on large cultural rifts-North and South, East and West, urban and rural, settled and frontier-that have long been the subject of historical inquiry, but rarely have been explored in a single data base useful to both social and political historians. Southern culture dominated areas west of the Chesapeake; shipping and agricultural interests controlled the Eastern Shore; Baltimore was a metropolis of national importance; the north central area surrounding Baltimore looked more to the North than the South for its cultural values; and the western panhandle evolved much like neighboring areas in the Northwest Territory. ${ }^{16}$ The state is a rich venue for exploring and altering our understanding of the now generally accepted notion that, during our early history, divorce was accessible to many in the North and few in the South. ${ }^{17}$ Recounting the Maryland legislature's work will bring these conflicts to life. 
During the earliest days of the republic, images of the family were central organizational features of political, religious, and economic understandings throughout the nation. Husbands and fathers served as a fulcrum for religious activity and distribution of political authority, simultaneously controlling the civic activities of their households and voting to send their landed peers to government service. The late eighteenth-century "corporate economy" of the Northeast, Mary Ryan teaches us, ${ }^{18}$ created similar devotional customs, with men serving as intermediaries between God and family, salvation and politics. Common law coverture, or marital property, rules gave husbands a like role, controlling both the economic relationships between the family and the outside world and the distribution of resources within the family itself. ${ }^{19}$

While many early Maryland households also may have been highly integrated "corporate" entities analogous to Ryan's corporate family, the variety of cultural motifs in the state made for a quite diverse set of family models. During the late eighteenth century, the Maryland General Assembly was dominated by landed and slaveholding elites surrounding the Chesapeake. Both the divorce rate ${ }^{20}$ and the passage rate $^{21}$ for legislative divorce petitions were lower in Maryland after the Revolutionary War than in the Northeast. On the surface at least, Maryland conformed to the general Southern pattern of granting divorces more reluctantly than other regions at the turn of the nineteenth century. ${ }^{22}$ But contrasting cultural forms similar to those found in the Northeast began to influence areas of the state, especially around Baltimore and in the western panhandle, after I800. New tensions developed in Maryland family law as the nineteenth century progressed.

During the first half of the nineteenth century, contests about political, religious, and economic roles of husbands and wives were prevalent throughout the North and West. Debates about limiting suffrage to male property owners emerged early in the century. Civic responsibility came to be shared among a larger class; property restrictions on male voting waned. ${ }^{23}$ As men moved out of the home to work, women gained recognition as teachers of domestic, cultural, and religious values. ${ }^{24}$ In many areas of the country, and in parts of Maryland, both spouses acquired new roles. Husbands and fathers, while retaining their position as political governors, became breadwinners. Wives and mothers, while continuing their household chores, became teachers and moral beacons. Faith also became more democratic. Salvation for many became an individual decision to be made rather than an outcome to be imposed by God. Women, deprived of political and economic power, often were attracted to this devotional message and integrated its teachings into their family life. Since salvation required good deeds on earth, maintenance of an observant family became an essential good deed for women. Throughout, however, patriarchal families remained central, as a place for faithful religious observance, a site for inculcation of cultural values, and a training ground for adult exercise of civic responsibility.

Modification of marital property rules throughout the nation during the first decades of the nineteenth century, like changes in political and religious structures, left the essential features of the patriarchal family intact. Upon marriage, common law rules used in much of the nation during the Revolutionary War era gave a husband ownership of almost all of the personal property of his wife as soon as he reduced it to his possession. In addition, he also gained management rights over her real property for the life of the marriage. Upon the birth of a child, control over the wife's real property was extended to the lifetime of the husband. While early nineteenth-century reforms allowed some deserted women to regain their property or their economic independence and married women's property acts precluded attachment of a wife's property by creditors of her husband, men retained control over the central economic features of intact families.

Family formation rituals also changed after the Revolutionary War. Arranged marriages virtually disappeared. Romance emerged as a basis for mate selection. But such "freedom" did not reduce the impetus to marry. Family remained as a solid source of status and cultural location. The attractions of power remained for men; the promise of economic security attracted women; the legitimation of sexual behavior attracted both. In stark contrast with the present day, when images of rock-solid, politically attuned, churchgoing families often seem little more than nostalgic symbols called to duty by desperate politicians, early nineteenth-century adults expected to marry, raise a family, develop a family economy, and stay together 'til death did they part.

Many of these developments influenced Maryland. Property restrictions on male access to the franchise were eased early in the nineteenth century, ${ }^{25}$ religious revivalism swept parts of the state, ${ }^{26}$ and married women's property law reforms were passed. ${ }^{27}$ But the traditional Southern undertones of much of Maryland society inevitably made debates about family discord prominent features of judicial and legislative discussions in the state. A number of forums existed for these family law debates. Though coverture rules employed by common law courts prevented 
spouses from contracting directly with each other, ${ }^{28}$ chancery courts enforced separation agreements in which husbands reposed assets in trustees for the benefit of their estranged wives. Couples therefore had the ability to privately settle many of their domestic differences. ${ }^{29}$ Maryland's chancery courts also had authority throughout the period to grant alimony to women whose husbands engaged in adultery or cruelty and refused to establish trusts for their separated wives. ${ }^{30}$ In addition, the 1829 session of the General Assembly enacted legislation granting courts authority to appoint commissioners to receive evidence and draft reports for use by divorce committees of the legislature. ${ }^{31}$ Other general divorce bills regularly came before the state legislature for debate. And, as already noted, the legislature passed a number of private divorce acts before $\mathrm{I} 85 \mathrm{I}$, when such matters fell completely into judicial hands. ${ }^{32}$

By mid-century, Southern influence over divorce standards waned but did not disappear. Citizens of Maryland were filing petitions seeking passage of private divorce acts at a rate of more than seventy per year. Maryland's legislative divorce rate was comparable to the judicial rates in other areas of the country. ${ }^{33}$ The rising influence of nonslaveholding western settlers, Eastern Shore farmers and traders, and Baltimore urbanites fueled a steady rise in the state's divorce rate. Watching this story unfold in a legislative arena provides dramatic evidence of regional and class differences in attitudes toward family law. Traditional, more aristocratic, Southern delegates continually voted against private divorce bills in large numbers, while representatives from other areas voted the opposite way. ${ }^{34}$

Telling stories about divorce in a political, legislative environment, placing the intact family at the focal point of cultural life is ironic history at its best. Tales of failure become the vehicle for expounding upon both ideal and flawed images of family culture, economic life, religious devotion, politics, and law. Recent social history literature has only begun to pry open this complex story. ${ }^{35}$ Norma Basch's work is a particularly good explication of Northeastern judicial divorce in the mid-nineteenth century. ${ }^{36}$ She carefully instructs us that the development of divorce was not a simple tale of women claiming new realms of autonomy in a world of disappointed romantic expectations. For many women, divorce only formally ended a marriage terminated earlier by a deserting husband. The courts enabled them to reconstruct their economic lives and, perhaps, to remarry. Those women with property of their own fared much better than those without, since alimony was of little use to women deserted by impoverished husbands. For the departed men, divorce served to sanction their leaving. In a nice reconstruction of prior work describing the rise of divorce as a claim by women for autonomy from the constraints of family culture, ${ }^{37}$ Basch paints a more interesting, complex picture in which the arrival of divorce freed deserting men to seek out new mates. "Men," Basch writes, "created de facto divorces, women sought out legal ones." 38 The nineteenth-century history of divorce in the Northeast, therefore, is not a linear story of gradual liberalization in the face of changing cultural norms and social pressures. Divorce, like much of women's legal history, was laden with double-edged consequences. ${ }^{39}$ Women, Basch tells us, might obtain some autonomy by divorce, but only at the expense of being labeled a failure in the moral education of their spouses. And the freedom from family constraints resulting from divorce was frequently tempered by economic insecurity, if not by abject poverty.

The complexities of electoral politics undergirding the private act divorce process add new dimensions to this tangled family law story. Many classic jurisprudential texts discuss the development of judge-made common law norms as a gradual, intensely fact-based creation of "rules." ${ }^{40} \mathrm{We}$ were told that these rules, while always subject to modification in new factual situations, gave guidance to the community at large and shaped the contours of legal debate. Stare decisis (the homage paid to the wisdom of prior decisions), it is assumed in such scholarship, restrained quixotic changes in the rules, making it easier to report on trends in legal attitudes and to predict the future behavior of courts. While many now dispute this simplistic, apolitical view of judicial behavior, there is a grain of truth to the notion that courts, constrained by the need to resolve specific disputes, often act cautiously, paying some deference to prior history and decisions. To whatever degree the image of courts as gradualist institutions reflects reality, it is clear that the Maryland General Assembly did not feel bound by many court-like restraints in its review of divorce petitions. The legislative process itself left much room for manipulation, both by those seeking divorces and those occupying the corridors of power. Resolution of factual controversies was not trial-like. And, most importantly, the apparent substantive "rules" of legislative divorce changed often, sometimes in quite remarkable, abrupt, and surprising fashions. The beginning and the end of Maryland's nineteenth-century divorce story was a bit like those in other places, but the body of the story is remarkably different.

The basic structure of the private act process was quite simple. Those seeking legislative divorces filed petitions stating their grievances and requests for relief with the General Assembly. Leave to file a petition was 
almost always sought by a member of the House of Delegates from the county or region in which the petitioner lived. Senators rarely initiated a divorce bill. Since members of the House of Delegates were at their homes scattered throughout the state during most of the year when the legislature was not in session, it was fairly easy and, absent great controversy, relatively inexpensive to initiate the divorce process. ${ }^{41} \mathrm{~A}$ visit with a delegate, perhaps followed up by the signing of an affidavit, could start the ball rolling. Each member of the House would simply bring divorce papers with him to each session. Though the famous and wealthy sometimes used the legislative divorce process, many of the cases involved middle-class or impoverished families. ${ }^{42}$

Until the House of Delegates established a standing divorce committee in 1822 , ad hoc committees were designated to review each petition and present a report or bill for review by the entire body. The delegate seeking leave to file the petition virtually always served on the ad hoc committee reviewing it. Evidence was generally not taken, though counter-petitions and affidavits were sometimes filed. Committee decisions on divorce petitions were rarely accompanied by reports stating reasons and opinions for the proffered recommendations. The process followed by divorce committees was often one-sided, especially in cases in which one spouse was no longer in the area or wished her or his spouse's petition to be well received. By 1840 there was clearly some room for cooperative couples wishing to divorce to proceed in an "uncontested" manner. ${ }^{43}$ Delegates interested in divorce also made their mark. Whether devotion to a cause, retribution for a slight, or performance of a personal favor motivated their interest, delegates were free to seek membership on committees reviewing divorce petitions, to work their will without the need to publicly state their reasons, and, as with all legislative disputes, to work the corridors of power.

In such an environment transformation of political party alignments or enlargement of the franchise had marked impacts on legislative family law policy. Those seeking divorces often found themselves at the mercy of larger political shifts. Expansion of the franchise and the rise of the Republican Party at the turn of the nineteenth century, for example, loosened the constraints on divorce prevalent in the largely aristocratic pre-1800 General Assembly. Before 1805 all the legislative divorces were obtained by men. Although some women sought a divorce, they were all turned aside. This pattern changed in 1806 . For the next decade, women petitioned for divorce more often than men, and with somewhat greater success. ${ }^{44}$
Political, combined with religious, events led to another abrupt change in legislative divorce patterns in 1816. Only a vinculo, or complete, divorces had been granted during the prior twenty-five years. ${ }^{45}$ That is, all prior parties to divorces were permitted to remarry after their legislative divorce act was passed; they were freed "from the chains" of marriage. But after the Federalists, led by Roger Brooke Taney, a Catholic, regained control of the Maryland Senate in I816, the legislature refused to pass a vinculo divorces. For the next decade, only a mensa et thoro, or partial, divorces were enacted. These acts freed men and women "from the obligation to share bed and board," but they could not remarry. While this hints of a conservative reaction in family law once the lively post-Revolutionary War debates on the role of women faded from view, ${ }^{46}$ the change in policy led the legislature to initiate a number of other changes that were not so traditional. New types of provisions appeared in the private acts, such as feme sole protections permitting women living apart from their husbands under partial divorces but still "bound by the chains of marriage" to participate in economic transactions otherwise precluded by marital property rules. Some women regained property they brought to their marriages or obtained other economic awards. Such benefits allowed women to escape from the more egregious depredations of departed husbands. In addition, the rate of success for women petitioning for legislative relief rose. ${ }^{47}$ Child custody provisions also became central features of the legislative debates during this time. ${ }^{48}$ The era, therefore, was traditional in some ways and reformist in others.

From I826 until the Maryland General Assembly first adopted general divorce legislation at its I84I session, ${ }^{49}$ the proportion of complete divorces among the enacted private bills gradually rose. There were disputes over the granting of complete divorces, with the State Senate sometimes blocking the adoption of $a$ vinculo bills and insisting on the passage of partial divorces. The last partial divorce was passed in the 1840 legislative session. After I84I, the legislature fitfully attempted to get out of the divorce business, leaving a batch of simple a vinculo divorces, much like that granted to Eliza Gibson, in its wake. During the few years before the state adopted its first general divorce act, more than seventy petitions for private bills were filed in each session. ${ }^{50}$ After adopting its first general divorce act, the legislature got out of the private bill business for a few years. Most assumed that the general act adopted in I84I had ended the legislative divorce process. Pressures to continue granting private divorces, however, arose from many parties, including a state governor, who could not obtain 
relief under the narrow divorce act governing judicial decision making Divorce petitions had returned to a high level by the time Maryland's I850 state constitutional convention opened its deliberations ${ }^{51}$ and, with minimal debate, inserted a provision in the new constitution banning legislative divorce.

Though divorce petitions did cast a burdensome pall over the legislature after 1840 , the disappearance of legislative divorce a decade later is not just a classic tale of frustration over individuated decision making leading a legislative body to push controversies into a judicial branch designed to handle one-on-one disputes. ${ }^{52}$ Despite the increasing pressure to grant divorces as the nineteenth century evolved and the palpable need to resolve the status of women left in legal limbo by departed men, those sitting in Maryland's General Assembly before 1850 were extremely reluctant to pass general divorce legislation. Such reluctance was quite remarkable, since a significant number of legislators voted in favor of private bills granting divorces on grounds the same officials refused to allow in general legislation. Individual plights of woe were one thing; broad approbation of divorce through reformist general legislation was quite another.

This is actually not an unusual phenomenon, though examples of it in nineteenth-century legal history have not previously been noted. Some of those adjudicating individual disputes - whether judges or legislators inevitably empathize with the plight of breathing human beings laying their problems before them for resolution. Such empathy will lead to results in individual cases that are not possible when general principles come under discussion. The history of the twentieth-century is littered with examples of this political dynamic. Individuals could obtain birth control devices from under drugstore counters, even as legislators refused to repeal broad regulatory limitations on their advertisement and distribution. ${ }^{53} \mathrm{In}$ dividual use of condoms was one thing; running the gauntlet of the political and religious right to propose lifting controls on distribution was quite another. Individuals seeking abortions in trying circumstances evoked sympathy from politicians who professed opposition to freedom of choice. Sherri Finkbine's widely publicized efforts to abort a thalidomide-affected fetus in the ro6os was one thing; general repeal of restrictions on abortion was quite another. ${ }^{54}$ In like manner, the mid-nineteenthcentury denouement of the divorce story in Maryland found a traditional, rather than reformist, coalition pushing the General Assembly out of the divorce business. By the 1840 s, those favoring liberal divorce preferred to maintain the legislature's right to grant divorces; those preferring a traditional family with restrictive access to divorce voted to ban private divorce bills and push family conflicts into the courts under narrowly drawn general legislation. The final result was a quite conservative divorce statute, left largely intact until 1937.55

Nonetheless, the shift of divorce to the courts was a significant historical event. It symbolized the lessening role of families as a central organizing force of religion, politics, and the economy. Industrial concerns, work places, markets, schools, and churches were all focal points for the exercise of power and the training of citizens. Family was becoming "private," and the resolution of "private" family matters in the "public," politically charged legislature was losing its aura of propriety. Eventually it became acceptable to contend that leaving divorce in legislative hands was "obviously" wrong "because it would occupy too much time, and because it is properly a judicial act." ${ }^{36}$ This book tells the convoluted story of how traditional politics made divorce "properly a judicial act."

\section{Notes}

I. See Table I in Appendix I. Between 1790 and I8sI one or both members of at least I,IOO couples filed I,386 petitions for divorces. Seventy-two couples filed three or more times. It is possible that I missed a few petitions or acts. The possibility of inaccuracies in the indexes for each year of the legislative journals and session laws cannot be eliminated. The early journals were often unindexed. The year a divorce is granted is normally described in both the tables and the text by reference to the date on which the legislative session in which the divorce was passed actually began, not the date the private act was formally adopted. Most sessions began late in one year and continued into the following calendar year.

2. An Act to Give to the Chancellor and the County Courts as Courts of Equity, Jurisdiction in Cases of Divorce, ch. 262, $184 \mathrm{I}$ Md. Laws (Mar. I, 1842) Complete divorce grounds were limited to impotence at the time of marriage adultery, abandonment for five years, and grounds traditionally available to annul a marriage, such as bigamy. Additional grounds were listed for a partial divorcecruelty of treatment, excessively vicious conduct, abandonment, and desertion. In other states, these grounds often served as a basis for obtaining a complete divorce. The courts also were granted authority to award alimony and property to wives, and custody and child support to either spouse.

3. In I85I, section 2I of a new state constitution forbade the General Assembly from granting private divorces.

4. This was almost surely the first Maryland divorce. Other searches of Maryland legislative records have also failed to turn up an earlier one. See M. K. Meyer, Divorces and Names Changed in MaryLand by ACt OF the LegISLATURE, I634-1854 (1970). Riley contends it was the first post-Revolutionary War legislative divorce in the South. G. Riley, Divorce: An American TraDITION 35 (199I) 
5. An Act for Annulling the Marriage of John Sewell, of Talbot County, and Eve his Wife, ch. XXIV, I790 Md. Laws (Dec. 2I, 1790). Although the word "annulling" is used in the title of the Sewell divorce act, it was not an annulment The body of the legislation contains a vinculo divorce language, that is, language breaking "the chains" of marriage. In addition, the setting is one not traditionally handled by designating a marriage void at its inception.

6. Only seven, or less than 2 percent, of the 502 divorces adopted later con tained such language. This change occurred for two reasons. As Chapter 4 make clear, only divorces from bed and board were passed by the legislature between I816 and 1826 . The legitimacy of children is not cast in question by such divorces since the parents may not remarry. After 1826, when complete divorces reappeared no one felt that the legitimacy of children was at risk because of divorce.

7. Votes and Proceedings of the House of Delegates of the State of Maryland. November Session, 1788, at p. 68 (1789). (This series of volumes, which covers the entire period of this study, will be cited as [date] House JOURNAL at [page], with the appropriate year in which the legislative session began and the page reference provided. Similar citations will be given for the VoTES and Proceedings of the Senate of the State of Maryland, using the form [date] SenAte Journal at [page].)

8. An Act to Divorce Eliza Gibson, of the City of Baltimore, from $\mathrm{He}$ Husband, Edmund D. Gibson, ch. 558, I849 Md. Laws (Mar. 9, 1850). A vinculo matrimonii means "from the chains of marriage." Other divorces were granted a mensa et thoro, or "from bed and board." The latter technically left the parties married - free to live apart, but unable to remarry.

9. By I840, about 40 percent of all those petitioning the legislature for divorces and half of the couples actually divorced by private bills involved people from Baltimore City. See Tables 6 and 7 in Appendix I. Before 1805 those filing petitions with the state legislature were usually male. That changed after 180 s. About three-fifths of the petitioners were women from 1805 on. See Table 8 in Appendix I.

io. Compare L. Friedman, A History of American Law 500 (1985). And see Table 9 in Appendix $\mathrm{I}$, showing that Baltimore had a higher divorce rate than the rest of the state.

II. The legislative record is quite sparse. Maryland's General Assembly, like virtually every other nineteenth-century legislature, failed to archive its papers. This problem is one of the major reasons why private bills have been so rarely studied in the historical literature. Petitions, committee reports, and bill files were routinely destroyed. Although Maryland newspapers sometimes reported on leg islative events, they apparently were not interested in divorce. A search through many papers failed to produce any useful information. Despite the lack of extensive legislative records, a few sources exist for studying the legislative divorce process First, some court records of alimony and commission proceedings remain. They are, of course, interesting in their own right. In addition, they sometimes shed light on actions of the General Assembly, especially when the litigants were the same as those seeking legislative relief. Second, legislative journals, though not word-for-word transcripts of floor proceedings, provide a number of clues about the divorce process. Most of the journal entries are mundane reportage of bill and petition filings, committee appointments, committee conclusions, and floor votes Once in a while, committee reports were explicated, amendments explained, and debates summarized. The litany of routine procedural items recorded in the journals for each bill, together with the acts themselves, produced a useful computer data base. Information on the passage rate of bills, gender of petitioners, and residence of the parties, among other useful items, was retrieved and analyzed. From time to time, the journals also provided details about proposed amendments or other facets of floor debates on particular bills. Finally, there is a scattering of useful data in library, manuscript, and pamphlet collections.

12. See Tables 2 and 9 in Appendix I. Baltimore City divorce rates were higher than in the state at large after 1800 . Divorce rates for 1850 cannot be figured from the data in this study since both courts and the legislature granted divorces between I 842 and I85I. While I know the number of legislative divorces, I do not know the judicial divorce rate. The legislative data demonstrate that the number of divorce petitions filed in the legislature and the number of private divorce bills actually adopted declined markedly immediately after the courts obtained divorce jurisdiction in 1842

I3. "Collusive" divorce, while not common before I850, was not unknown. See Friedman, supra note IO, at 207-208. Some friendly divorces certainly passed Maryland's General Assembly during the first half of the nineteenth century. See the discussion in Chapter 7.

I4. The number of Maryland women receiving outpensions (payments to women unconstrained by obligations of servitude or debt imprisonment) in the opening decades of the nineteenth century increased significantly, especially in the cities. C. McKenna, Women, Welfare and Work in Maryland: A Historical Survey of the First Two Hundred Years 25-29 (1982) (Student paper on file with author).

I5. Norma Basch, in her recent article on divorce in New York and Indiana, Relief in the Premises: Divorce as a Woman's Remedy in New York and Indiana, I8IS-I870, 8 LAW \& HIST. REV. I (1990), paints a striking portrait of the women and men left behind by migrating spouses.

I6. In this study, these regions are broken down into the following counties:

North Central Region: Baltimore, Frederick, and Harford Counties

Eastern Shore Region: Caroline, Cecil, Dorchester, Kent, Queene Annes, Somerset, Talbot, and Worcester Counties

Southern Region: Anne Arundel, Calvert, Charles, Montgomery, Prince Georges, and Saint Marys Counties

Western Region: Allegany and Washington Counties

17. See Friedman, supra note IO, at 204-206.

18. M. Ryan, Cradle of the Middle Class: The Family in Oneida COUNTY, New YORK, 1790-I865, at 22-43 (198I).

19. R. Chused, Married Women's Property Law: 1800-1850, 71 Geo. L. J. I359, I36I-1372 (1983).

20. M. Schultz, in Divorce in Early America: Origins and Patterns in Three North Central States, 25 SOC. Q. 5II, 518 (1984), reports that the divorce rate for a sample of counties in Illinois, Missouri, and Ohio was 8 per 100,000 in 1810, 4 in 
1820, 9 in 1830 , and 14 in 1840 . For the early decades of the nineteenth century, Maryland's rates were consistently lower, although those for Baltimore City alone crept closer to the Schultz findings. By 1840 , the statewide rate rose to just under 7 per 100,000 and the rate in Baltimore to more than 18 . See Table 9 in Appendix I.

21. Schultz, supra note 20 , at 520 , also reports that 48.1 percent of legislative divorce petitions were adopted in $1820,59.0$ percent in $1830,62.3$ percent in 1840 , and 67.I percent in 1850 . Maryland's passage rates were somewhat lower, though as with divorce rates, passage rates rose to levels comparable to those in Northern states by 1840 . By then about half of the legislative divorce petitions led to divorce acts. See Table 2 in Appendix I.

22. Statutes granting courts authority to issue divorces were adopted later in the South than in the Northeast. Passage of legislative divorces, though more common in the South than others areas, probably did not occur often enough to equalize regional divorce rates in the first half of the nineteenth century. RILEY, supra note 4, at 25-29, 34-44; M. Schultz, Divorce in the South Atlantic States: Origins, Historical Patterns, and Recent Trends, I6 INT'L. J. Soc. FAM. 225, 245 (1986). The best study of divorce in the South is J. Censer, "Smiling Through Her Tears": Ante-Bellum Southern Women and Divorce, 25 AM. J. LEG. HIST. I (198I).

23. See R. Steinfeld, Property and Suffrage in the Early American Republic, 4I StAN. L. REV. 335 (1989).

24. L. KERBER, WOMEN OF THE REPUBLIC: INTELLECT \& IDEOLOGY IN EVOlUtionary AMERICA 269-288 (1980).

25. R. Brugger, Maryland: A Middle Temperament, I634-1980, at 160-I66 (1988).

26. $I d$. at $\mathrm{I} 47-\mathrm{ISI}$.

27. Chused, supra note 19, at 1365-1381, 1399.

28. The often-stated ground for this and other rules was that husband and wife were one entity. Since an entity may not contract with itself, spouses were unable to make legally binding agreements. The most commonly used statement of this "logic" may be found in ch. XV, part III on the law of husband and wife in BLACKSTONE's COMMENTARIES, an English treatise first published in 1765. The most prominent early American edition of Blackstone, edited by St. George Tucker, Professor of Law at the College of William and Mary, was published with heavy commentary in 1803 in Philadelphia.

29. See M. Salmon, Women and the Law of Property in Early AMERICA 66-76 (1988)

30. Section XIV of An Act Concerning Marriages, ch. XII, 1777 Md. Laws provided " $[\mathrm{t}]$ hat the Chancellor shall and may hear and determine all Causes for Alimony, in as full and ample Manner as such Causes could be heard and deter mined by the Laws of England in the ecclesiastical Courts there." Ecclesiastica courts allowed bed and board divorces for adultery or cruelty. This statute confirmed a long-standing practice in the state. M. SALMON, supra note 29 , at $62-63$; G. May, Divorce LAW in Maryland: Interim Report of the Study of DIVORCE LITIGATION IN OHIO AND MARYLAND 3-6 (1932).

31. An Act for Taking Testimony in Cases of Applications for Divorce, ch. 202, 1829 Md. Laws (Feb. 27, 1830).
32. From 1842 to 1849 , divorces emanated from both the courts and the legislature. There was no r85o legislative session while the state constitutional convention was in session.

33. See Schultz, supra note 20, at 518; Schultz, supra note 22.

34. See Table $\mathrm{I} 3$ in Appendix $\mathrm{I}$, showing that for most time periods delegates from the South favored private divorce bills at lower rates than delegates from other areas.

35. For general summaries of divorce law before and just after the Revolutionary War, see G. RILEY, supra note 4 , at I-I29; M. SALMON, supra note 29 , a 58-80; N. M. Blake, RoAd to Reno: A History of Divorce in the United States 34-96 (1962); L. C. Halem, Divorce Reform: Changing Legal and Social Perspectives 9-26 (1980). For studies of particular jurisdictions in the same eras, see Basch, supra note is; S. Cohen, The Broken Bond: Divorce in Provi dence County, I749-1809, 44 R.I. Hist. 67 (1985); S. Cohen, "To Parts of the World Unknown": The Circumstances of Divorce in Connecticut, 1750-1797, II CAN. REv. AM. STUD. 275 (1980); N. Cott, Divorce and the Changing Status of Women in EighteenthCentury Massachusetts, 33 WM. \& MARY Q. 586 (1976); N. Cott, Eighteenth Centur Family and Social Life Revealed in Massachusetts Divorce Records, Io J. Soc. Hist. 20 (1976); C. Dayton, Women Before the Bar: Gender, LaW, ANd Society IN Connecticut, I710-1790, at 284-376 (1986) (Thesis, Princeton U.); T. Meehan, "Not Made Out of Levity": Evolution of Divorce in Early Pennsylvania, 92 PA. MAG. Hist. \& Bio. 44I (I968).

36. Basch, supra note is.

37. Contrast, Friedman, supra note io, at 50I-502 (1985); C. Degler, At Odds: Women ANd the FAmily in America from the Revolution to the PRESENT I68-I69 (1980).

38. Basch, supra note is, at 8 .

39. Compare the attractions of married women's property laws to traditional men, discussed in R. Chused, The Oregon Donation Act of 1850 and Nineteenth Century Federal Married Women's Property Law, 2 LAw \& HIST. Rev. 44, 69-73 (1984), and radical reformers.

40. See, e.g., E. Levi, An Introduction to Legal Reasoning (1948). 4I. The ease of gaining access to members of the House of Delegates suggests that the legislative divorce process was not any more expensive, and maybe less expensive, than the judicial divorce process.

42. Divorce broadened into a largely middle-class remedy in many areas in the nineteenth century. See FrIEdMan, supra note 10, at 500-50I.

43. See id. at 207-208.

44. See Tables 3 and 8 in Appendix I. These data show that the proportion of women petitioners jumped from 33 percent to 60 percent after 1804 , and the passage rate for women from zero to 26 percent.

45. See Table I

46. See, e.g., the discussion of this era in KERBER, supra note 24, at 269-288. 47. See Table 3 in Appendix I, showing that the passage rate for women petitioners jumped from 26 to 45 percent.

48. See Table 4 in Appendix I for data on the timing of custody, name 
change, and property distribution issues in enacted private bills. Between 1816 and 1825 , Is percent of the acts contained child custody provisions. No custody provisions appeared in earlier legislation. About half of the $1816-1825$ acts also contained provisions on the rights of husbands in the property of wives. These data confirm other work showing that child custody and property issues emerged as serious issues early in the nineteenth century. See, e.g., M. Grossberg, Governing THE Hearth: Law and the Family in Nineteenth Century America 234-28 (1985); J. Zainaldin, The Emergence of a Modern American Family Law: Child Custody, Adoption and the Courts, $1796-185$ I, 73 Nw. L. REV. 1038 (1979); N. BASCH, IN the Eyes of the Law: Marriage and Property in Nineteenth-Century New York (1982); Chused, supra note 19, at 1404-1409 (1983).

49. An act to give to the Chancellor and the County Courts as Courts of Equity, jurisdiction in cases of Divorce, ch. 262, 184I Md. Laws (Mar. I, 1842). The act provided for complete divorces only for adultery, impotence, marriages unlawful from the beginning (such as marriages between relatives), or abandonment from the state for five years. Cruelty was a ground for bed and board divorce. The abandonment ground was amended a few years later to reduce the period to three years and to remove the requirement that the departed spouse be out of state.

50. Seventy-eight petitions were filed in the 1838 session, 73 in 1839,74 in 1840 , and 75 in 1841 , the year the general legislation was adopted.

5I. No private bills were enacted during the 1842,1843 , and 1844 legislative sessions, and only II petitions were filed during those years. Then the filings and adoptions began to grow again, with 43 petitions filed in the 1847 session and 71 in 1849 .

52. Contrast Friedman, supra note IO, at 206.

53. See E. Chesler, Woman of Valor: Margaret Sanger and the Birth Control Movement in AMerica (1992).

54. See K. Luker, Abortion ANd the Politics of Motherhood 62-9i (1984); E. R. Rubin, Abortion, Politics, AND the Courts: RoE V. WADE AND ITS AfTERMATH 29-55 (1982). Thalidomide, an experimental sedative, was distributed in samples by physicians in the United States. When taken during pregnancy, it caused major deformities of the arms and legs of the baby. Newspaper reports of the birth defects led Ms. Finkbine to seek an abortion. Her complex attempts during 1962 to abort a fetus after learning she had taken thalidomide produced quite different reactions in the public press from those of the myriad right-to-life demonstrations of the past two decades. Finkbine's plight was widely and often sympathetically reported in the press. See the coverage of the Finkbine story in the N.Y. TimES, July 25 , 1962, at 22 ; July 26 , 1962, at 25 ; July 31 , 1962, at 9 ; and Aug. 19, 1962, at 69. She eventually flew to Sweden to obtain an abortion when Arizona authorities refused to allow it. D. Tarka, Thalidomide: The Drug Companies' Fallacy (1991) (Student paper on file with the author). After abortion was legalized, the ability to empathize with individuals disappeared in a stormy moral, ethical and religious debate.

55. Maryland adopted a voluntary separation ground in 1937, the first major change in divorce law since the mid-nineteenth century. Matysek v. Matysek, 128 A.2d 627, 63I (1957).
56. This statement was made by Edward Otis Hinkley of the Baltimore Bar in an appendix to an I855 edition of the new Maryland Constitution. THE CONSTItution of the State of Maryland, Reported and Adopted by the Convention of Delegates Assembled at the City of Annapolis, November 4TH, i850, and Submitted to and Ratified by the People on the First WedNeSDAY OF June, I851, at 78 (E. O. Hinkley ed., I855). 